Studia i materiały $\mathrm{z}$ dziedzictwa kulturowego Torunia i regionu,

t. 1: STARE I NOWE DZIEDZICTWO TORUNIA,

Toruń 2013

http://dx.doi.org/10.12775/SiMzDzKTiR_T1.2013.017

Anna Mosingiewicz

(IZIK UMK, TORUŃ)

\title{
Pomniki Bąkowskich w kościele św. Jana Chrzciciela i św. Jana Ewangelisty w Toruniu - historia i fundacja
}

„Factum abiit; monumenta manent” - czas mija; pomniki jego pozostają. Te słowa Owidiusza (Fasti, 4, 709) mogą stanowić motto do poniższych uwag, z konieczności podanych w skróconej formie, które początkiem sięgają moich badań nad jednym z epitafiów rodziny Bąkowskich znajdujących się w kaplicy św. Stanisława Kostki w kościele pw. św. Jana Chrzciciela i św. Jana Ewangelisty w Toruniu. Epitafium Elżbiety Joanny z Czeszewa Bąkowskiej (il. 1) zwracało uwagę swoją wielkością, skalą, intrygowało niespotykaną, oryginalną formą i ikonografią, zmuszało do zastanowienia nad przyczynami jego niepełnej, nieukończonej struktury ${ }^{1}$. Błędne jednak okazało się traktowanie go jako dzieła wyabstrahowanego, wyłączonego z najbliższego otaczającego go kontekstu. Dopiero dokładniejsze rozpoznanie innych obiektów w jego bezpośrednim sąsiedztwie, w przestrzeni tej samej kaplicy, dało pełniejszy, choć wciąż nie pozbawiony znaków zapytania, historyczny i semantyczny obraz.

Pomijam tu wszelkie dokładniejsze opisy i analizy, ograniczając uwagi do zaprezentowania zweryfikowanej, podstawowej faktografii, postawienia kilku, wybranych z szerszego kwestionariusza pytań i przedstawienia niektórych propozycji, które mogą być pomocne dla nakreślenia pełniejszego obrazu całości. Składają się nań, oprócz wspomnianego monumentu jeszcze dwa inne, historycznie ściśle z tym pierwszym związane pomniki - przez co rozumieć należy zarówno dzieła architektoniczno-rzeźbiarskie o charakterze sepulkralnym, wzniesione dla upamiętnienia, uczczenia konkretnych osób, jak i utrwalone świadectwa przeszłości, ważne ze względu na ich wartość historyczną i artystyczną pamiątki/zabytki.

1 Mówiłam o tym przy okazji sesji naukowej zorganizowanej przez Oddział Toruński SHS-u (marzec 2002) poświęconej zabytkom kościoła św. św. Janów w Toruniu. Pierwszym badaczem, który zwrócił uwagę na wyjątkowy charakter i oryginalność struktury tego pomnika „rodziny Bąkowskich” był W. Tatarkiewicz. Zob. Władysław TATARKIEWICZ, Nagrobki z figurami klęczącymi, [w:] TENŻE, O sztuce polskiej XVII i XVIII wieku. Architektura. Rzeźba, Warszawa 1966, s. 429-430; stwierdza on: „Jest to niedokończony pomnik Elżbiety Joanny Bąkowskiej z czarnego i brunatnego marmuru i alabastru; był przeznaczony dla dwóch osób, ale dla drugiej - dla męża - ani popiersie, ani inskrypcja nie zostały umieszczone. Kompozycja tego pomnika jest wyjątkowa: oryginalność jego polega na tym, że zmarła jest przedstawiona dwukrotnie, w popiersiu i w całej figurze na klęczkach, że popiersie jest umieszczone w polu sześciobocznym kształtu trumiennego, a figura klęcząca ustawiona jest nie w ramie pomnika, lecz nad nią, powyżej gzymsu”. 
Drugim jest epitafium Katarzyny z Wiesiołowskich i Aleksandra Bąkowskich (il. 2 i 3), usytuowane na tej samej południowej ścianie, pod oknem z lewej strony kaplicy, kolejnym zaś płyta nagrobna w posadzce $\mathrm{z}$ wykutymi na niej herbami. O ile literatura wzmiankująca te zabytki jest skąpa, o tyle liczba przeinaczeń lub też zwykłych pomyłek - odwrotnie do tego proporcjonalna, i to (co zastanawiające) prawie w każdym aspekcie: dat śmierci, miejsca pochówku, czasu powstania epitafiów, a nawet niektórych elementów ich formy ${ }^{2}$. Pewne sugestie, dotyczące treści ideowych, znaleźć możemy jedynie u Władysława Tatarkiewicza ${ }^{3}$ i Mariusza Karpowicza ${ }^{4}$.

Datowanie, a zatem i kolejność powstawania tych dzieł trudna jest do jednoznacznego określenia, ale pewne wskazówki znajdujemy w samych zabytkach oraz w literaturze heraldycznej. Bezsporna jest osoba fundatora - Jana Ignacego Bąkowskiego (ur. ok. 1615 zm. 1679 r.). To do niego odnosi się wzmianka w inskrypcji epitafijnej, zarówno w pomniku poświęconym Elżbiecie Joannie z Czeszewskich zmarłej w roku 16625 , w której mowa jest o mężowskim żalu po śmierci pełnej wszelakich cnót i zalet młodo (w wieku 30 lat) zmarłej żony, jak i w skromniejszym pod względem rozmiarów i programu epitafium poświęconym rodzicom, gdzie - obok typowej dla epoki retoryki wychwalania cnót zmarłych małżonków i ich godziwego życia - znajduje się następujący passus: „przenieśli się na tamten świat i przykryci kamieniem ufundowanym przez syna.”(il. 4). Katarzyna z Wiesiołowa zmarła 16 września 1657 roku, jej mąż Aleksander de Nostiz Bąkowski - kilka lat później, w roku $1663^{6}$.

Z kolei określenie „wspólnie pochowani”, występujące w tekście inskrypcji, bardziej zaciemnia niż wyjaśnia kwestię daty pochówku, a pośrednio i powstania epitafium. Może od-

2 TATARKIEWICZ 1966, s. 429, autor - uważa, iż epitafium Aleksandra i Katarzyny Bąkowskich „wydaje się jeszcze bardziej odrębne niż naprawdę jest, przez to, że górą brak mu ramy, która uległa zniszczeniu”. Nie ma jednak żadnych przesłanek, które wskazywałyby, że klęczące po obu stronach krucyfiksu figury małżonków w szczycie posiadały jakąkolwiek ramę; zostały one zakomponowane w sposób analogiczny do figur stanowiących zwieńczenie pomnika Elżbiety z Czeszewa Bąkowskiej. Z kolei Jerzy Domasłowski sądzi, że jej rzeźbiarski portret w popiersiu wykonano „Z czerwonego i czarnego marmuru” (a nie z alabastru, jak jest w rzeczywistości), zob. Jerzy DOMASŁOWSKI, Wyposażenie wnętrza, [w:] Bazylika katedralna świętych Janów w Toruniu, red. M. BISKUP („Zabytki Polski Północnej” 12, TNT), Toruń 2003, s. 210.

3 TATARKIEWICZ 1966, s.429-430, por. też przyp. 1.

4 Mariusz KARPOWICZ, Trzy przerzuty do Polski rzymskiej awangardy w XVII wieku, [w:] TENŻE, Sztuki polskiej drogi dziwne, Bydgoszcz 1994, s. 50, il. III.12. Autor zauważa fakt umieszczenia figur klęczących małżonków Bąkowskich na tle okna, z krzyżem między nimi, „który wedle sugestii anonimowego do dziś autora, jest źródłem światła dla całego układu”. Widzi w tym inspirację ołtarzem w Cappella Alaleona Berniniego w zakresie wykorzystania światła „adaptowanego”, tzn. światła padającego w oczy jako części składowej, jako istotnego elementu kompozycji, chociaż równocześnie epitafium to uznaje za „prowincjonalne i zgoła niezauważone”.

5 Julius Emil WERNICKE, Die Kirchen der Stadt Thorn und ihres Gebietes, 1830, rkp, Archiwum Państwowe w Toruniu, sygn. II, X 25, s. 112 (W); opis epitafiów zamieszczony u Johana HEISEGO, Die Bau- und Kunstdenkmäler des Kreises Thorn / bearb. in Auftrage dest Westpreussischen Provinzial-Landtages, Danzig 1889, s. 263. Por. także Danuta KRAKOWIECKA-GÓRECKA, Toruńskie inskrypcje kościelne do końca XVIII wieku, cz. II (katalog), „Rocznik Toruński”, t. 19, 1990, s. 297. Autorka podaje wymiary tablicy epitafijnej (67 x $66 \mathrm{~cm}$ ), typ pisma i technikę (kapitała humanistyczna, kuta wklęsło) oraz przytacza treść inskrypcji.

6 Takie daty śmierci małżonków znajdują się w tekście inskrypcji epitafijnej oraz w herbarzach; za pomyłkę należy uznać rok 1657 podany jako data śmierci Aleksandra Bąkowskiego, zob. DOMASŁOWSKI 2003, s. 209. 
nosić się ono zarówno do właściwego miejsca pochówku7, które - co prawdopodobne znajduje się w krypcie kaplicy św. Stanisława Kostki, jak też tylko do epitafium, jako trwałego upamiętnienia zmarłych rodziców (niekoniecznie związanego z ich grobem). Świadek tamtej epoki, Jan Karol Dachnowski stwierdza, iż Katarzyna Bąkowska, córka Marcina Wiesiołowskiego, siostra Jana, kasztelana elbląskiego, pochowana została w Dźwierz$n e^{8}$. Jej małżonek, według tego samego autora, umarł w Chełmży ${ }^{9}$. Czy został tam pochowany, podobnie jak inni przedstawiciele rodziny Bąkowskich (synowie jego brata Piotra), czy może spoczął we wspólnym grobie z żoną w Dźwierznie - źródło milczy. Należy wziąć pod uwagę i taką możliwość, że doczesne szczątki obojga rodziców fundatora ich toruńskiego pomnika zostały przeniesione do Torunia po śmierci wojewody pomorskiego i malborskiego Aleksandra Bąkowskiego w 1663 r. i złożone we wspólnym, rodzinnym grobie w Świętojańskim kościele. Aktowi synowskiej fundacji epitafium, ad oculos dla współczesnych i potomnych, mógł towarzyszyć pochówek rodziców w grobie, który wtedy zapewne już istniał, bo przeznaczony był dla zmarłej rok wcześniej młodej żony, a w przyszłości i dla niego samego.

Jako świadectwo takiego stanu rzeczy można potraktować dużą kamienną płytę o rozm. 172 x 119 cm w posadzce kaplicy, z dwoma wyrytymi na niej herbami (il. 5): u góry Bąkowskich - Ryś, a poniżej Czeszewskich, co oznacza, że przeznaczona była do przykrycia grobu żony Jana Ignacego i jego samego, a nie wyklucza pogrzebania w nim również rodziców. Kacper Niesiecki, wspominając o Katarzynie Wiesiołowskiej zaślubionej Alexandrowi Bąkowskiemu, stwierdza dobitnie: „ta w Toruniu u S. Jana 1666 leży” ${ }^{10}$. W innym miejscu ten sam autor pisze jednak: „W Toruńskim S. Jana kościele pochowany [Aleksander Bąkowski], ostatniego dnia oczekiwa, i z żoną swoją, czego świadkiem jest kamień grobowy marmurowy w r. 1663, położony"11.

Nie rozstrzygając daty pochówku rodziców razem czy osobno, w roku 1663 czy 1666, podkreślić należy kluczową rolę Jana Ignacego w całości przedsięwzięcia, a także zapytać, czy sam fundator został tu pochowany? Na obecnym etapie badań czas powstania pomników Bąkowskich wiązać należy z datami śmierci członków jego najbliższej rodziny, możliwościami finansowymi oraz całą logistyką związaną z zamówieniem projektu i realizacją epitafiów. Wszystkie te czynniki powodowały określone ograniczenia i trwanie w czasie. Przypomnijmy, że w przeciągu zaledwie kilku lat zmarły trzy najbliższe osoby z rodziny Jana Ignacego: jego matka (1657 r.), żona (1662) i ojciec (1663). A zatem rok 1663 należałoby traktować jako terminus post quem, zaś rok 1671 jako termin ad quem powstania toruńskich

7 Bogusław MANSFELD, Toruń i okolice. Przewodnik, Warszawa 1983, s. 65, zdaje się tak mniemać, stwierdzając: „Na posadzce kaplicy płyta marmurowa na ich grobowcu”, na co jednak nie wskazują znajdujące się na niej herby.

8 Jan Karol DACHNOWSKI, Herbarz szlachty Prus Królewskich z XVII wieku, odczytał, wstępem i przypisami opatrzył Z. PENTEK, Kraków 1995, s. 27.

9 TAMŻE, s. 170. „Umarł potem Pan Aleksander w Chełmży in anno 1653 [sic] die 24 Decembris [24 XII 1653]”.

10 Herbarz polski Kaspra NIESIECKIEGO S. J.: powiększony dodatkami z poźniejszych autorów, rękopismów, dowodów urzędowych, wyd. J. N. BOBROWICZ, T. 10, Lipsk 1842 [dalej cyt. NIESIECKI 1842], s. 326.

11 TAMŻE, T. 2, Lipsk 1839 [dalej cyt. NIESIECKI 1839], s. 48. 
pomników, bowiem w opisie wizytacji biskupiej kościoła św. św. Janów ks. Ludwika Strzesza z 1671 roku odnotowano już ufundowane przez Jana Ignacego Bąkowskiego „marmurowe epitafia" rodziców i żony znajdujące się w kaplicy św. Stanisława Kostki ${ }^{12}$.

Kolejno po sobie następujące bolesne wydarzenia w życiu Bąkowskiego niewątpliwie głęboko go doświadczyły, zapewne też umocniły wiarę i nadały kierunek jego działalności fundatorskiej, stając się także bezpośrednim impulsem dla idei wystawienia pomników nagrobnych. Miały one jednocześnie upamiętniać bliskich zmarłych (memoria), stanowić skierowane ku przyszłości wyznanie wiary (wymiar eschatologiczny), jak też - co było równie ważne - upamiętniać społeczną i majątkową pozycję fundatora i rodziny (monumentum). Funkcji tych nie spełniał sam kamień nagrobny z herbami. Warto dodać, że wspomniane trzy funkcje pomników nagrobnych są wyraźnie widoczne w strukturze epitafiów Bąkowskich. Odpowiadają im kolejno: tablice z inskrypcją, postaci klęczących zmarłych w pozie wiecznej adoracji zwrócone ku Ukrzyżowanemu Chrystusowi (il. 6, 7) i w sposób niespotykany w innych realizacjach sepulkralnych tego czasu wyniesione w najwyższą strefę zwieńczenia, jakby ku lub już w niebie (w epitafium Elżbiety Bąkowskiej postaci te umieszczone są na tle wielkiego okna wychodzącego na południe, co wzbogaca przekaz o symbolikę światła), oraz herby. W epitafium żony silnym akcentem wzmacniającym ekspresję i treści ideowe jest prawie pełnoplastyczny jej portret, ujęty w ramy „sarmackiego” portretu trumiennego (il. 8), stanowiąc swoistą manifestację przekonań polityczno-ideologicznych i religijnych fundatora.

W latach sześćdziesiątych XVII wieku J. I. Bąkowski rozwijał aktywną działalność fundatorską, która wsparta musiała być na odpowiednich możliwościach finansowych. Ufundował klasztor oo. reformatów w Kiszporku, klasztor i kościół pw. św. Antoniego Padewskiego dla oo. reformatów w Gdańsku, które w roku 1666 „Z gruntu...wystawił, swojej na Boga szczodrobliwości nieumierającą pamiątkę"13. Był też hojnym dobroczyńcą kolegium jezuickiego w Gdańsku' ${ }^{14}$. Wspierał zapewne również jezuitów toruńskich ${ }^{15}$. Nie można wykluczyć, że koncentrował się na utrzymaniu i opiece nad kaplicą św. Stanisława Kostki, w której posiadał kryptę grobową i fundował dzieła sztuki sepulkralnej. Świętojańska „capellas. Stanislai Costcae, Societatis Iesu confessoris, recenter beatficati, canonisationis proximae"16, na pewno zaspokajała ambicje szlacheckiego działacza i polityka oraz wiernego syna Kościoła, zarówno przez osobę swojego młodocianego patrona, wywodzącego się z pomorskiego rodu (nowe patrocinium), jak też ze względu na korzystne jej położenie - stosunkowo blisko prezbiterium, przy południowej nawie świątyni.

W omawianym okresie Bąkowski był już popularnym wśród szlachty pomorskiej działaczem politycznym, który reprezentował Prusy Królewskie na sejmach i aktywnie bronił

12 Visitationes episcopatus Culmensis Andrea Olszowski Episcopo A. 1667-72 factae, „Fontes” (TNT Societas Literaria Torunensis), t. 7, 1903 [dalej cyt. VISITATIONES], s. 200.

13 NIESIECKI 1839, s. 48.

14 DACHNOWSKI 1995, s. 27.

15 Nie udało się znaleźć informacji wskazujących bezpośrednio na taką działalność J. I. Bąkowskiego, pośrednio na tego typu ugruntowane już związki mogą wskazywać dary ofiarowane kościołowi śś. Janów w Toruniu przez jego drugą żonę Konstancję Annę z Denhoffów.

16 VISITATIONES, s. 200. 
przywilejów ziem pruskich. Od 1662 roku był podskarbim pruskim, w roku 1665 wszedł do senatu jako wojewoda pomorski. Był przywódcą partii francuskiej na terenie Prus Królewskich, regalistą, stronnikiem, sekretarzem i zaufanym króla Jana Kazimierza, później bliskim współpracownikiem Mikołaja Jana Prażmowskiego i Jana Sobieskiego, doradcą króla w sprawach pruskich. Uczestniczył w misjach dyplomatycznych i w komisjach dotyczących spraw politycznych, między innymi występował w sporach gdańskich po stronie cechów przeciw radzie miejskiej, radząc królowi zajęcie Pucka i osadzenie załogi polskiej w Gdańsku. Walnie przyczynił się do utrzymania wojska w służbie króla na Pomorzu dla ewentualnej akcji przeciwko elektorowi brandenburskiemu. Ostatniej swojej misji - zbadania spraw spornych z elektorem - już nie dokończył, zmarł bowiem w Gdańsku 25 grudnia 1679 roku, po dłuższej chorobie. ${ }^{17}$

Gdzie zatem spoczęły doczesne szczątki powszechnie znanego prusko-polskiego polityka i zaufanego króla? W Gdańsku czy w Toruniu? Można przypuszczać, że zgodnie z ówczesnymi zwyczajami i zaleceniami, po co najmniej 48 godzinach, gdy akt śmierci stał się faktem, został przewieziony do Torunia, czemu sprzyjała też zimowa pora roku, aby spocząć w rodzinnym grobie. Odpowiedź na to pytanie leży w granicach możliwości współczesnej nauki: badania DNA mitochondrialnego, którymi posługują się min. archeolodzy, umożliwiają stwierdzenie pokrewieństwa matka - syn, a zatem po odkryciu grobowca, jeśli zachowały się w nim szczątki Bąkowskich, tajemnica ich pochówku mogłaby ostatecznie zostać wyjaśniona. Osiągnięta w ten sposób wiedza, jakkolwiek frapująca, raczej nie zbliżyłaby historyków sztuki do uściślenia datowania epitafiów Bąkowskich. Pomogłaby jednak wesprzeć tezę o świadomym dążeniu Jana Ignacego do przekształcenia kaplicy św. Stanisława Kostki, której był kolatorem, w rodową nekropolię, odzwierciedlającą nowy status rodziny, która ze średnioszlacheckiej, dzięki jego działalności, w drugiej połowie XVII wieku znalazła się na dłużej wśród pruskiej oligarchiii ${ }^{18}$.

Zostawiamy na boku analizę koncepcji ideowej, która to koncepcja - co warte podkreślenia - jest szczególnie interesująca w pomniku Elżbiety z Czeszewa Bąkowskiej (opozycja herb - portret w świetle antropologii obrazu, a także zestawienie portret - figura w pozie genuflexio w kontekście kultury i religijności sarmackiej, dają tutaj nowe możliwości interpretacyjne). Pomijamy też kwestię niewątpliwych analogii z epitafiami z rzeźbiarsko opracowanymi figurami klęczącymi związanymi z uczniami i naśladowcami sztuki gdańskiego warsztatu van den Blocków. Ich działalność w zakresie architektury i rzeźby, odcisnęła się, jak wiadomo, wyraźnym piętnem na sztuce Gdańska. Promieniowała również na inne regiony Rzeczypospolitej (godna uwagi jest tu przede wszystkim twórczość Wilhelma Richtera).

Warto natomiast zwrócić uwagę na aspekt materiałowo-technologiczny, który ujawnił się dzięki pracom konserwatorskim, przeprowadzonym ostatnio przy epitafium Katarzyny

17 Kazimierz PIWARSKI, Bąkowski Jan Ignacy, [w:] Polski Słownik Biograficzny, T. 1, Kraków 1935, s. 382- 383; Tadeusz ORACKI, Słownik biograficzny Warmii, Prus Książęcych i Ziemi Malborskiej od połowy XV do końca XVIII wieku, t. 1, Olsztyn 1984, s. 17 (Bąkowski Jan Ignacy); Stanisław ACHREMCZYK, Bąkowski Jan Ignacy, [w:] Słownik Biograficzny Pomorza Nadwiślańskiego, red. S. GIERSZEWSKI, t. 1, Gdańsk 1992, s. 79-80.

18 Jerzy DYGDAŁA, Krzysztof MIKULSKI, Zmiany w elicie władzy Prus Królewskich w XV-XVIII wieku. (Czynniki awansu, trwania i upadku), [w:] Szlachta i ziemiaństwo na Pomorzu w dobie nowożytnej XVI-XVIII wieku. (Przemiany struktur wewnętrznych), red. J. DYGDAŁA, Toruń 1993, s. 12. 
i Aleksandra Bąkowskich ${ }^{19}$. Po zdjęciu późniejszych warstw malarskich z ramy, detali ornamentalnych i figur w zwieńczeniu widać wyraźnie, że mamy tu do czynienia z piaskowcem gotlandzkim Burgsvik, który był powszechnie stosowanym materiałem w rzeźbie i architekturze gdańskiej, a także na innych terenach Rzeczypospolitej. Tzw. „kamienie szwedzkie” przywożono w ogromnych ilościach, głównie jako balast statków, z wysp Olandia i Gotlandia na Bałtyku ${ }^{20}$. Zestawienie i mapa zabytków z terenu całej Rzeczypospolitej Obojga Narodów, wykonane przez Michała Wardzyńskiego pokazują niezwykłą skalę i zasięg importów kamieni i rzeźby kamiennej z Olandii i Gotlandii oraz długie trwanie tego zjawiska (od XIII do XVIII wieku ${ }^{21}$.

Ze względu na swoją drobnoziarnistą, porowatą i dość jednorodną strukturę piaskowiec gotlandzki dość łatwo poddawał się obróbce kamieniarskiej, umożliwiał wydobycie skomplikowanych form rzeźb i ornamentu. Używano go do wykonywania portali, obramień okiennych, okładzin ścian budowli, jak również rzeźby figuralnej, ram, ornamentu i detali w nagrobkach i epitafiach ${ }^{22}$. Jako przykłady podobnego zastosowania tego samego kamienia, co w epitafium toruńskim, można wskazać nagrobek Kosów w Oliwie, epitafium Feliksa Dąbrowskiego czy epitafium anonimowej rodziny z drugiej ćwierci XVII wieku w kościele św. Mikołaja w Gdańsku. Co więcej, sposób ujęcia klęczących postaci, ich proporcje, ułożenie rąk oraz sposób wydobycia wolumenu bryły i opracowania jej powierzchni, a także szczególny realizm w odtwarzaniu fizjonomii i faktury materii znajdują analogie z dziełem toruńskim.

Kwestią trudną do rozstrzygnięcia jest kolorystyka tych rzeźb, jak i całych epitafiów czy nagrobków, zazwyczaj źle lub w ogóle niezachowana. Uwzględniając jednak przykłady licznych odkryć konserwatorskich należy stwierdzić, że powszechna była praktyka pokrywania polichromią „powierzchni wszystkich elementów architektonicznych i rzeźbiarskich wykonanych z piaskowca - bez względu na miejsce ekspozycji, wewnętrznej czy zewnętrznej"; kamień często we fragmentach złocono, wzbogacając w ten sposób jego nieatrakcyjną powierzchnię oraz plastykę rzeźb, ornamentów i detalu architektonicznego. Rzeźby kamienne malowano najczęściej w konwencji naturalnej, tzn. malowano karnacje, usta, oczy, włosy i barwne szaty tak, by przypominały prawdziwe ${ }^{23}$. Dzieło niepomalowane uchodziło za nieukończone. Zanim pokryto kamień polichromią jego „powierzchnię nasycano gorącym pokostem w celu jej uszczelnienia, następnie nanoszono warstwę gruntu i dopiero na niej kładziono warstwy malarskie i złocenia. Malowano najczęściej w technice olejnej lub kaze-

19 Prace renowacyjne przeprowadzone zostały w 2012 roku pod kierunkiem prof. Jadwigi Łukaszewicz z Instytutu Zabytkoznawstwa i Konserwatorstwa UMK. Pani Jadwidze Łukaszewicz dziękuję za zwrócenie uwagi na epitafium Katarzyny i Aleksandra Bąkowskich i umożliwienie mi śledzenia prac przy nim.

20 Zob. mapa ukazująca typy i miejsca wydobycia szwedzkich skał wykorzystywanych w architekturze Pomorza i Szwecji: Piotr Paweł WOŹNIAK, Skały Szwecji i ich eksploatacja, [w:] Danuta KRÓL, Piotr Paweł WOŹNIAK, Leszek ZAKRZEWSKI, Kamienie szwedzkie w kulturze i sztuce Pomorza, Gdańsk 2004, s. 7-22, ryc. 7, s. 14.

21 Michał WARDZYŃSKI, Import kamieni i dzieł rzeźby z Gotlandii i Olandii do Rzeczypospolitej (od XIII do 2. połowy XVIII w.), „Porta Aurea”, t. 9, Gdańsk 2010, s. 45-119, il. 1, s. 46 (tu też obszerna literatura przedmiotu).

22 ZAKRZEWSKI 2004, s. 37-56.

23 TAMŻE, s. 39. Panu Leszkowi Zakrzewskiemu składam podziękowania za cenne uwagi i fachowe konsultacje w tej kwestii. 
inowo-olejnej. Polichromia, oprócz roli dekoracyjnej, spełniała funkcję ochronną, warstwy malarskie bowiem przez jakiś czas chroniły kamień (...)”24. Ponadto obowiązywała zasada i moda naśladowania szlachetniejszych, droższych i trudno dostępnych materiałów, stąd powszechne w XVII i XVIII wieku tzw. imitacje „na marmur”, „na alabaster”, „na brąz”, a w XVIII stuleciu również „na porcelanę”. Zawodowo trudnili się tym nie rzeźbiarze, lecz ich koledzy „po fachu” - malarze, pozostający zresztą dość długo w jednym cechu z rzeźbiarzami tak, co możemy zaobserwować w Toruniu jeszcze w XVIII wieku²5.

\section{EPILOG}

Powróćmy raz jeszcze do kwestii pomnika (monumentum), tym razem o charakterze literackim, ściśle związanego z osobą Jana Ignacego Bąkowskiego (co sprawia, że jego postać mutatis mutandis jeszcze bardziej przywodzi na myśl inną znaną osobistość w Toruniu, a mianowicie o niemal dwa pokolenia młodszego Jakuba Kazimierza Rubinkowskiego (1668-1749).

Jan Ignacy po raz drugi wstąpił w związek małżeński ${ }^{26}$, jego żoną została Konstancja Anna Denhoff z magnackiej rodziny, wywodzącej się z Inflant. Z tej radosnej okazji w oficynie Dawida Fryderyka Rhetego w Gdańsku wydano druk okolicznościowy autorstwa Michała Webera ${ }^{27}$, stanowiący wielką rzadkość ${ }^{28}$ (il. 9). Na odwrocie karty tytułowej znajduje się stemmat $\mathrm{z}$ miedziorytem, ukazującym wyobrażenia heraldyczne obojga małżonków: Rysia Bąkowskich i głowę dzika Denhoffów, ujęte w tarczę w kształcie serca w osobnych polach o zarysie przypominającym blastule, którą otaczają jakby języki ognia - symbolizujące zapewne gorące uczucia małżonków (il. 10, 11) 29. Subskrypcja zaczerpnięta z zawartych w Moraliach „Zaleceń małżeńskich” Plutarcha, jest pochwałą przyjemności, słodyczy i uroków małżeństwa, które płyną z wzajemnej uczynności i rozmowy (czego symbolem powin-

24 TAMŻE, s. 41.

25 Anna MOSINGIEWICZ, Emanuel OKOŃ, O obrazach, skrzynce cechowej i „sztukach towarzyskich”. Uwagi o kształceniu artystycznym $w$ Toruniu i Gdańsku na marginesie działalności Christiana Ernsta Ulricha, osiemnastowiecznego malarza w Toruniu, „Zapiski Historyczne”, t. 75, z. 1, 2010, s. 31-64.

26 Fakt mógł być jedną z przyczyn nieukończenia epitafium jego i pierwszej żony w kościele św. św. Janów, które pomyślane zostało jako podwójne, małżeńskie. Nie udało się ustalić daty ślubu z Konstancją Denhoff.

27 Michael Weberus, Pompa nuptialis quam illustrissimo et exellentissimo Domino, Domino Joanni Ignati á Bąkowo Bąkowsk Comiti a Nosticpalat. Pomeraniae thesaurario Prussiae, connubium secundum ineunti cum illustrissima sponsa, domina Constantia â Dönhoff Kosowa, palat. culm. Exhibita, .Gedani, Charactere David Friderici Rhetii, [b.r.] BG PAN sygn. 88in: Ma 3980 2o oraz 65 in: Nl 60 4o; także Biblioteka Główna UMK sygn. Pol. 7.III.690. Tylko w pierwszym $\mathrm{z}$ wymienionych egzemplarzy zamieszczona została rycina $\mathrm{z}$ herbami o emblematycznym charakterze.

28 Karol ESTREICHER, Bibliografia polska, Cz. III. (Obejmująca druki stuleci XV-XVIII w układzie abecadłowym). Ogólnego zbioru T. 32, Kraków 1938, s. 274. Odnotowuje tylko egzemplarz w Ossolineum „Z herbem na odwr.[ocie] [strony] tyt.[ułowej]". Chodzi więc zapewne o rycinę stanowiącą wyobrażenie plastyczne, imago, stemmatu.

29 O ich symbolicznym znaczeniu i pochodzeniu z emblematyki miłosnej może świadczyć inne, w znacznej mierze analogiczne, choć późniejsze dzieło - epitafium serca Marianny z Czarnkowskich Krasińskiej z kościoła reformatów w Węgrowie, powstałe w latach 1745-51, por. KARPOWICZ 1994, s. 169, il. IX.17; Katalog Zabytków Sztuki w Polsce, t. 10, Województwo warszawskie, red. I. GALICKA i H. SYGIETYŃSKA, z. 26, Powiat węgrowski, Warszawa 1964, s. 35, fig. 100. 
no być, zalecane przez Solona, wspólne spożywanie w łożu jabłka kydońskiego, czyli owocu pigwy ${ }^{30}$. Ale czy doszło do tego małżeństwa? Jakaś ręka dopisała na stronie tytułowej jednego z egzemplarzy datę ukazania się druku, a więc i owej Pompa nuptialis - „1686”, czyli siedem lat po śmierci pana młodego i rok po śmierci jego oblubienicy. Inny z kolei opatrzony został datą „1678”, a więc rok przed śmiercią, po dłuższej chorobie, Jana Ignacego. Byłby to zatem jedyny chyba w dziejach tego rodzaju przypadek. Nie można więc uznać za prawdziwą żadnej z tych dat ślubu Bąkowskiego z Denhoffówną. Dopiero dalsze badania, pozwolą być może ustalić czas tego ważnego w życiu obojga wydarzenia. Na obecnym ich etapie możemy jedynie wysunąć ostrożne przypuszczenie, że po raz drugi w związek małżeński Jan Ignacy Bąkowski wstąpił około połowy lub w drugiej połowie lat sześćdziesiątych XVII wieku. A zatem raz jeszcze objawił się przewrotny duch Historii (rodziny Bąkowskich) plączący proste drogi uczonych rozważań.

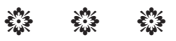

\section{The Bąkowskis' Monuments in St. Johns' Church in Toruń - history and foundation}

The subject matter of the remarks to follow are the monuments of the Bakowskis family from the chapel of St. Stanislau Kostka in St. Johns' Church in Torun, dating back to the 1660s, as well as a remnant of writing equally closely linked with that Pomeranian family, found in the collections of the PAN (Polish Academy of Science's) Library in Gdansk and in the collections of the UMK (Nicolaus Copernicus University's) Library's Old Prints Department. The two epitaphs in the Torunian church founded (ar. 1615-1679) by Jan Ignacy Bakowski, the Podkomorzy of Chetmno, commemorate his first wife, Elżbieta Joanna from Czeszewo, as well as his parents, Katarzyna of the Wiesiołowskis and Aleksander de Nostic Bakowski. The third sepulchral monument is a tombstone placed on the floor of that same chapel, containing two emblems only: the Lynx - of the Bąkowskis and the Crown - of the family de Bunin Czeszewskis, whose last representative was Jan Ignacy's wife. A comprehensive look at these works, not by accident joined not only by the shared chapel space but also by the person of their founder, allows us to undertake an attempt at determining a yet more precise time of their erection, the burial place as well as some elements of their form and genesis.

In the literature published so far the epitaphs of the Bakowskis are merely mentioned; the number of misrepresentations, however, or just common mistakes in connection with each of the above-mentioned issues makes you wonder. The contents of the inscriptions found on both Bąkowskis monuments as well as the literature on coats of arms and the biographies concerning

30 PLUTARCH Z CHERONEI, Moralia. Wybór pism filozoficzno-popularnych, przełożyła i oprac. Zofia ABRAMOWICZÓWNA, Wrocław 2005, s. 52. W polskim przekładzie z greckiego oryginału odpowiedni passus jak następuje: „Solon nakazał, by oblubienica, zanim podzieli łoże z oblubieńcem, spożyła jabłko kydońskie; dawał w ten sposób, jak się zdaje, do zrozumienia, że od pierwszej chwili z ust i głosu wionąć powinien zjednywający i nęcący powab”. 
the person of Jan Ignacy Bakowski, all constitute the source basis used to identify the person of the founder and they also, indirectly, allow us to determine the date of erection of the Torunian monuments (between 1663 and 1671, but rather closer to the earlier date) as well as formulate a hypothesis concerning the place of the burial of J. I. Bakowski's parents and wife. Thus, the chapel of St. Stanislaus Kostka in the Saint John's Church takes on the status of a mausoleum of a clan and a reminder in its own kind of its greatness.

The recently conducted renovation of the epitaph of Aleksander and Katarzyna Bakowski in turn (in 2012) and the related technical and technological studies enable us to draw conclusions regarding the origin of its stone and colouring.

In the epilogue, a so far unknown occasional print by Michael Weber has been presented, one published in Gdańsk for the occasion of Jan Ignacy Bąkowski and Constance Denhoff wedding. This unique print, provided with an interesting stemma, is the lastest example of monumentum - a monument, a document and a historical item - this time literary in character connected with the Bakowskis family. 


\section{SPIS ILUSTRACJI:}

1. Toruń, kościół pw. św. Jana Chrzciciela i św. Jana Ewangelisty, epitafium Elżbiety z Czeszewa Bąkowskiej, ok. 1663 r., fot. A. Skowroński.

2. Toruń, kościół pw. św. Jana Chrzciciela i św. Jana Ewangelisty, epitafium Katarzyny i Aleksandra Bąkowskich, ok. 1663 r. Stan przed konserwacją, fot. A. Skowroński.

3. Toruń, kościół pw. św. Jana Chrzciciela i św. Jana Ewangelisty, epitafium Katarzyny i Aleksandra Bąkowskich, ok. 1663 r. Stan po konserwacji, fot. A. Skowroński.

4. Tablica inskrypcyjna z epitafium Katarzyny i Aleksandra Bąkowskich, fot. A. Skowroński.

5. Toruń, kościół pw. św. Jana Chrzciciela i św. Jana Ewangelisty, herby na płycie nagrobnej w kaplicy św. Stanisława Kostki: Czeszewskich (po lewej) i Bąkowskich (po prawej), fot. A. Mosingiewicz.

6. Postacie klęczące małżonków Aleksandra i Katarzyny Bąkowskich, fragment z epitafium, fot. A. Skowroński.

7. Portrety małżonków Aleksandra i Katarzyny Bąkowskich, fragment z epitafium. Stan przed konserwacją (u góry) i po konserwacji (na dole), fot. A. Skowroński.

8. Portret Elżbiety z Czeszewa Bąkowskiej, fragment z epitafium. Fot. A. Skowroński

9. Strona tytułowa z druku Michaela Webera Pompa nuptialis... Biblioteka Gdańska PAN, fot. A. Mosingiewicz.

10. Stemmat z druku Michaela Webera Pompa nuptialis... Biblioteka Gdańska PAN, fot. A. Mosingiewicz.

11. Strona z druku Michaela Webera Pompa nuptialis... bez ryciny. Biblioteka Gdańska PAN, fot. A. Mosingiewicz. 


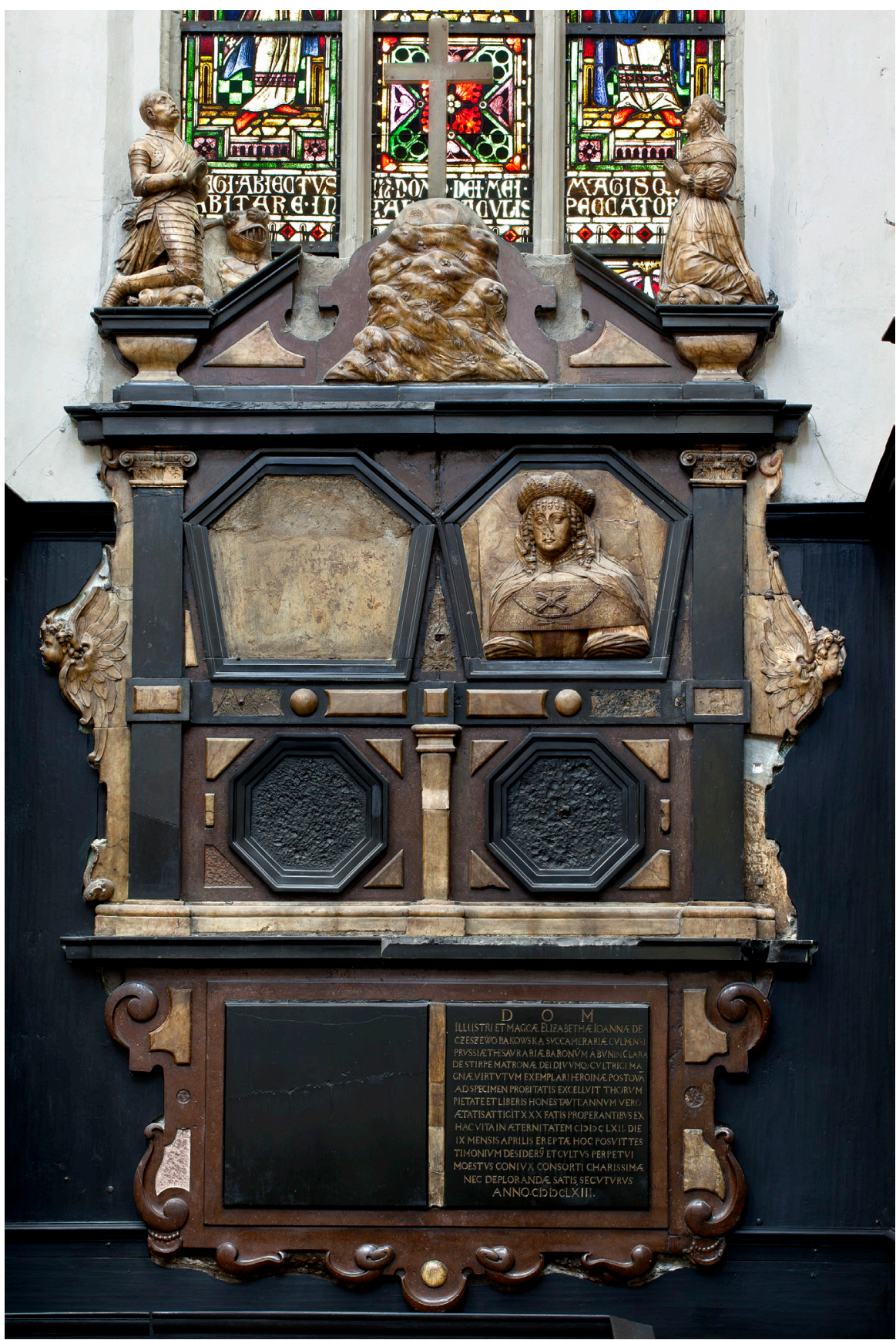

Il. 1 Toruń, kościół pw. św. Jana Chrzciciela i św. Jana Ewangelisty, epitafium Elżbiety z Czeszewa Bąkowskiej, ok. 1663 r., fot. A. Skowroński 


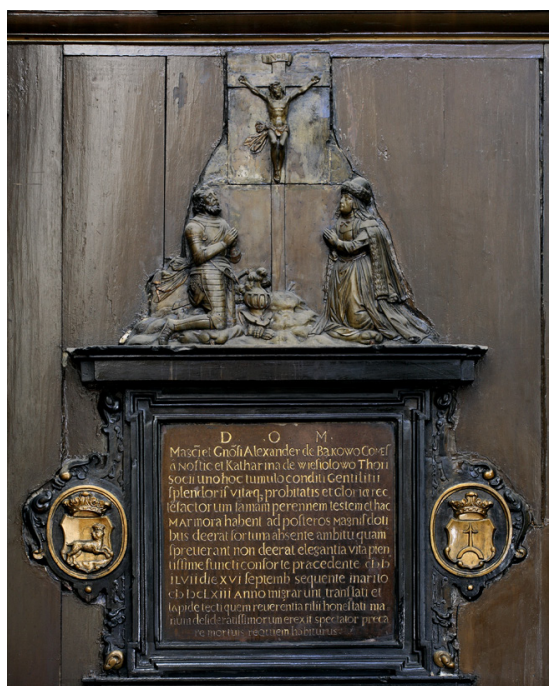

Il. 2 Toruń, kościół pw. św. Jana Chrzciciela i św. Jana Ewangelisty, epitafium Katarzyny i Aleksandra Bąkowskich, ok. 1663 r. Stan przed konserwacją, fot. A. Skowroński.

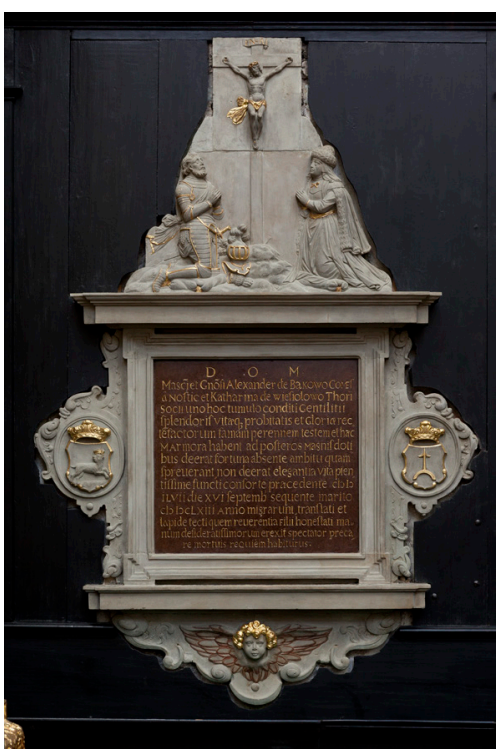

Il. 3 Toruń, kościół pw. św. Jana Chrzciciela i św. Jana Ewangelisty, epitafium Katarzyny i Aleksandra Bąkowskich, ok. 1663 r. Stan po konserwacji, fot. A. Skowroński 


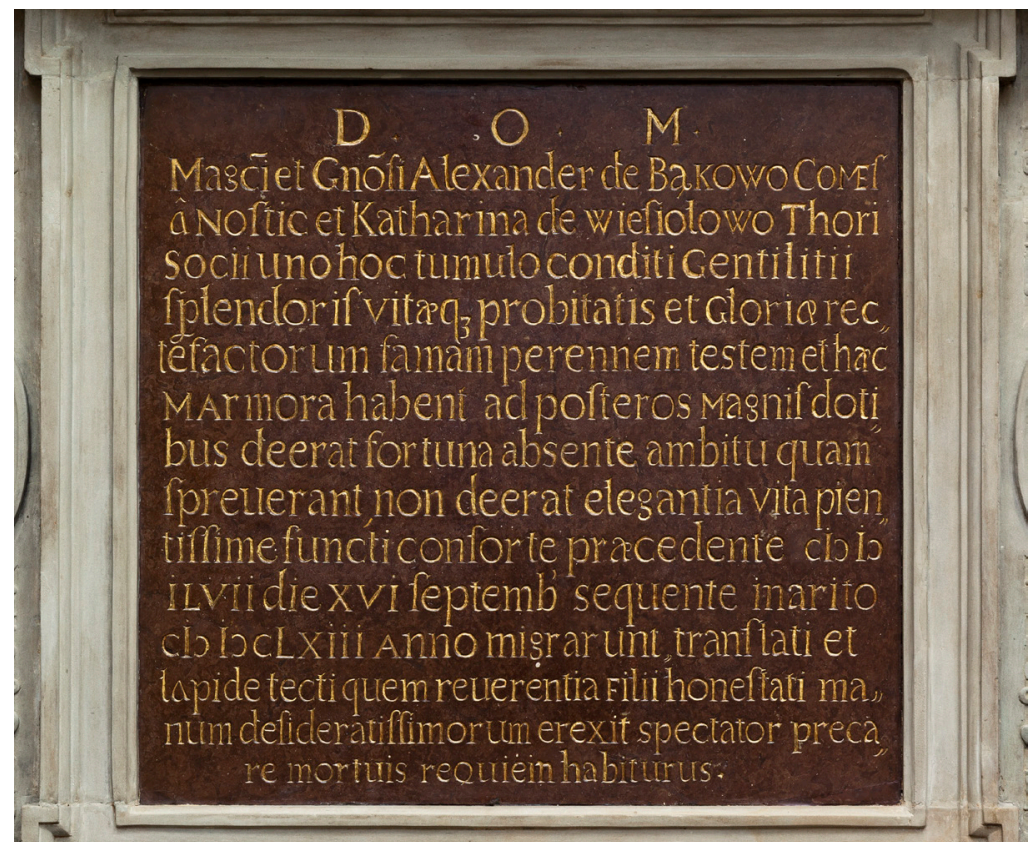

Il. 4 Tablica inskrypcyjna z epitafium Katarzyny i Aleksandra Bąkowskich, fot. A. Skowroński
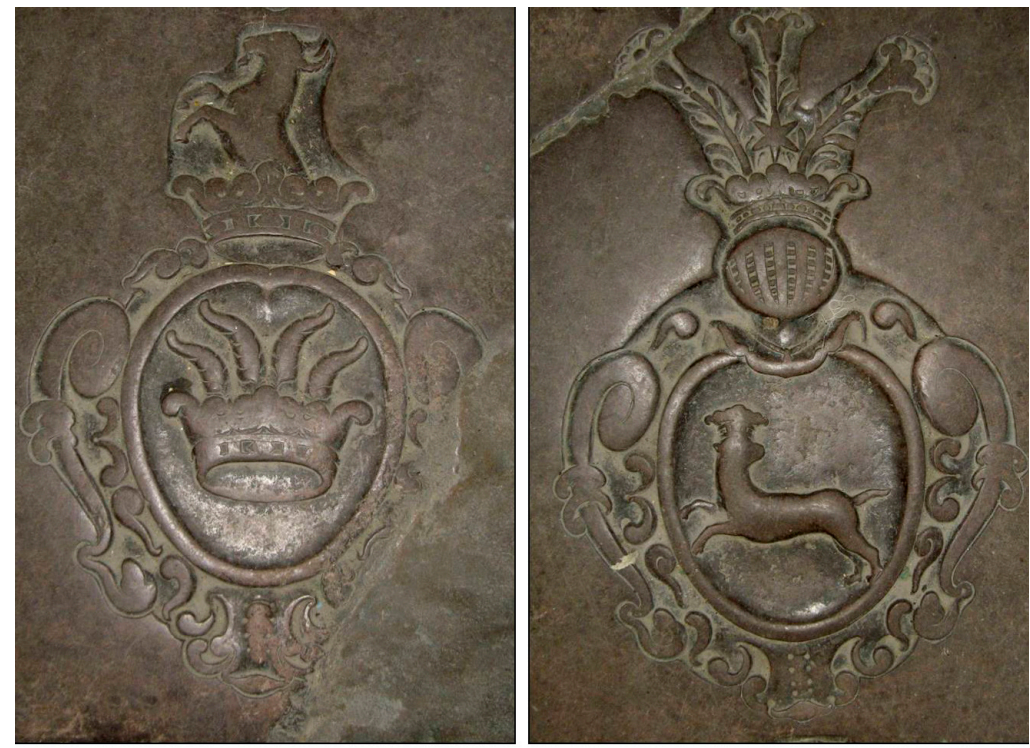

Il. 5 Toruń, kościół pw. św. Jana Chrzciciela i św. Jana Ewangelisty, herby na płycie nagrobnej w kaplicy św. Stanisława Kostki: Czeszewskich (po lewej) i Bąkowskich (po prawej), fot. A. Mosingiewicz 

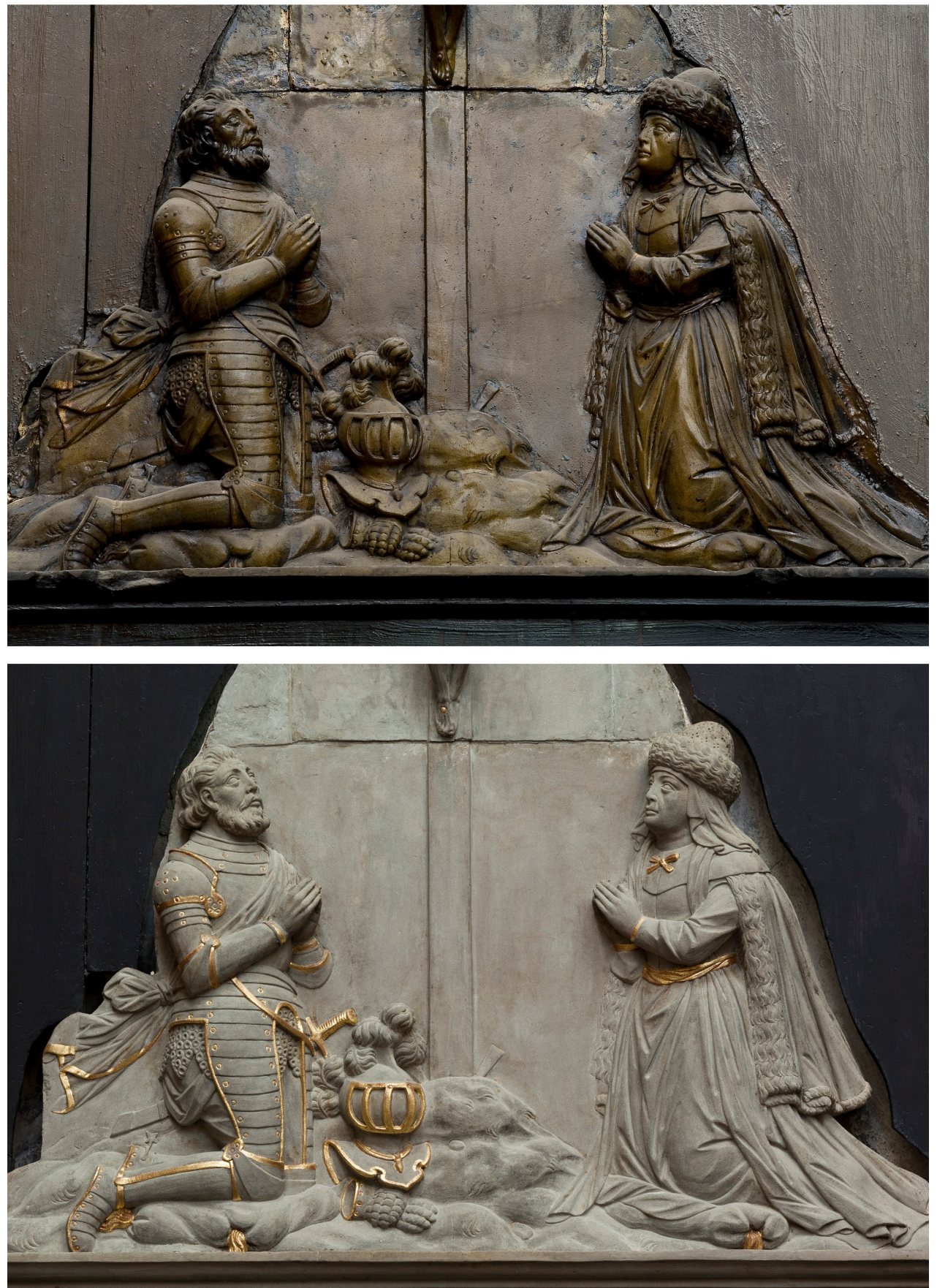

Il. 6 Postacie klęczące małżonków Aleksandra i Katarzyny Bąkowskich, fragment z epitafium, fot. A. Skowroński 

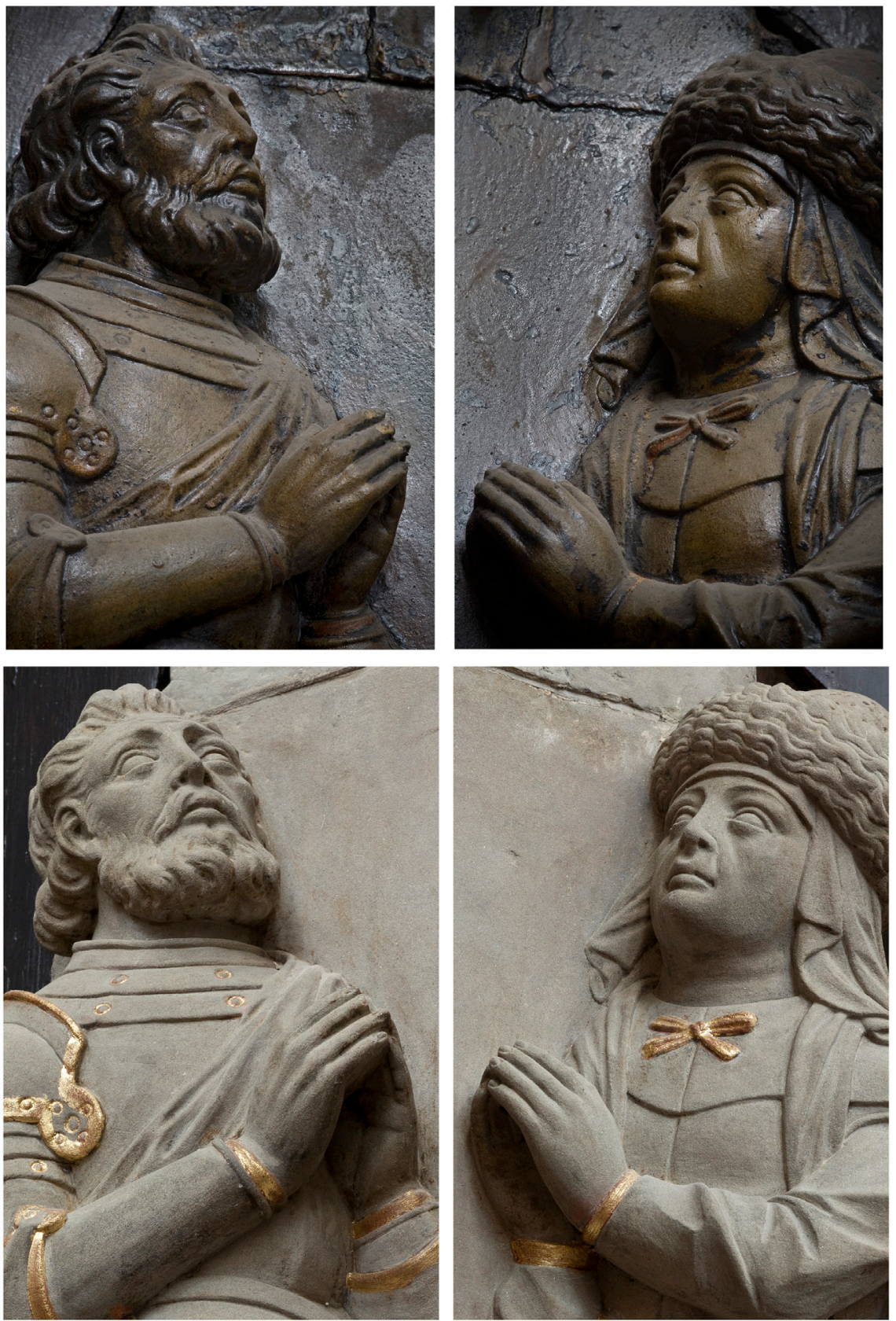

Il. 7 Portrety małżonków Aleksandra i Katarzyny Bąkowskich, fragment z epitafium. Stan przed konserwacją (u góry) i po konserwacji (na dole), fot. A. Skowroński 


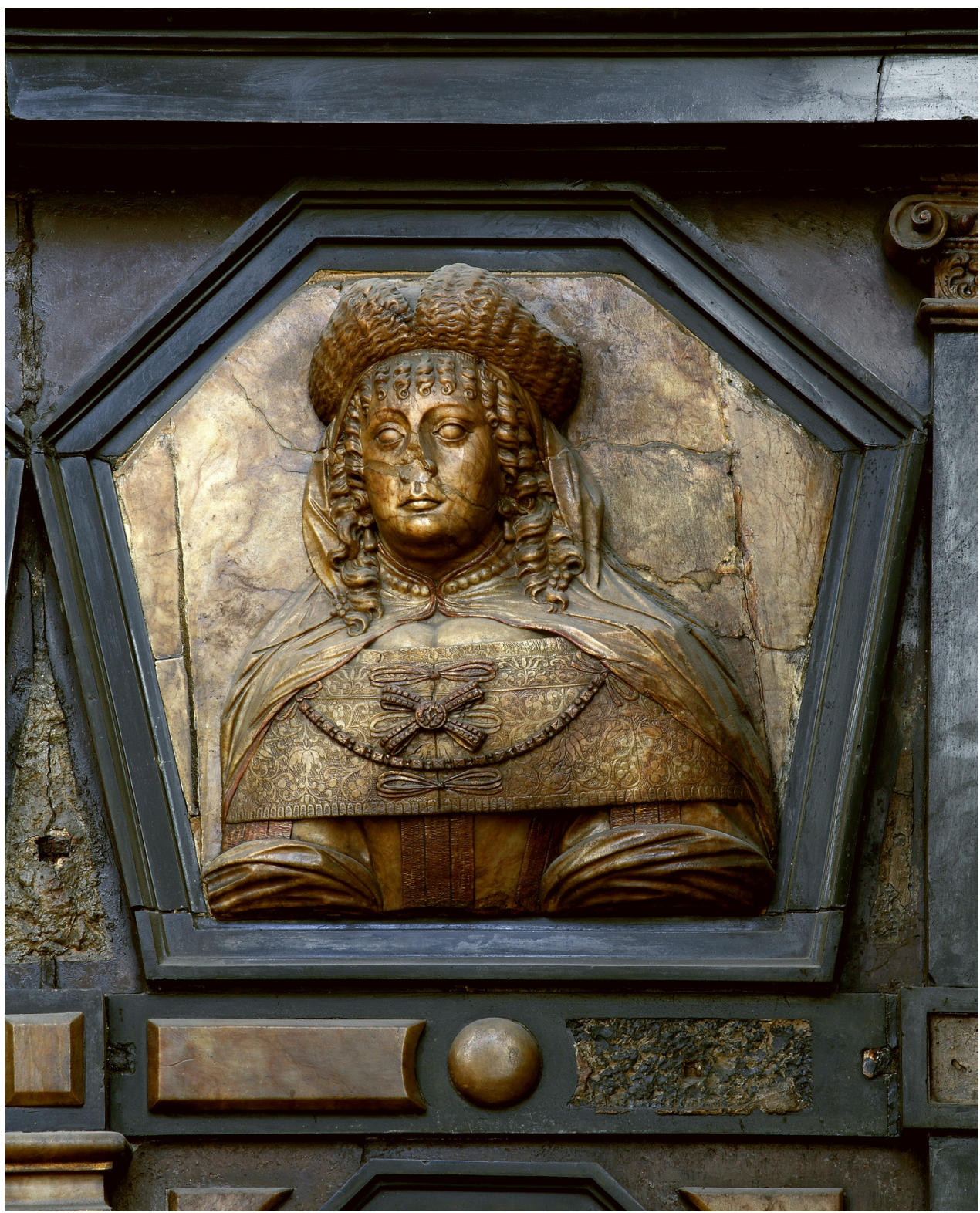

Il. 8 Portret Elżbiety z Czeszewa Bąkowskiej, fragment z epitafium. Fot. A. Skowroński 


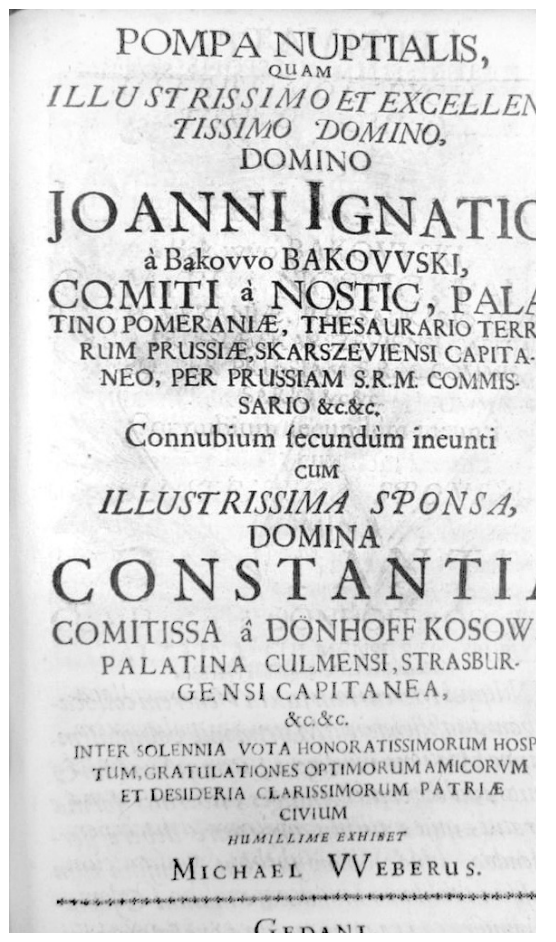

Il. 9 Strona tytułowa $\mathrm{z}$ druku Michaela Webera Pompa nuptialis... Biblioteka Gdańska PAN, fot. A. Mosingiewicz

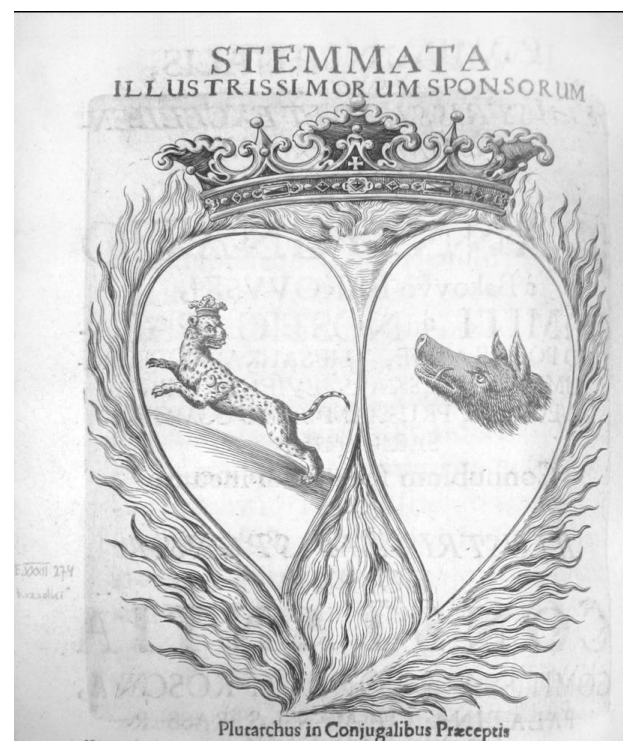

Il. 10 Stemmat $\mathrm{z}$ druku Michaela Webera Pompa nuptialis... Biblioteka Gdańska PAN, fot. A. Mosingiewicz

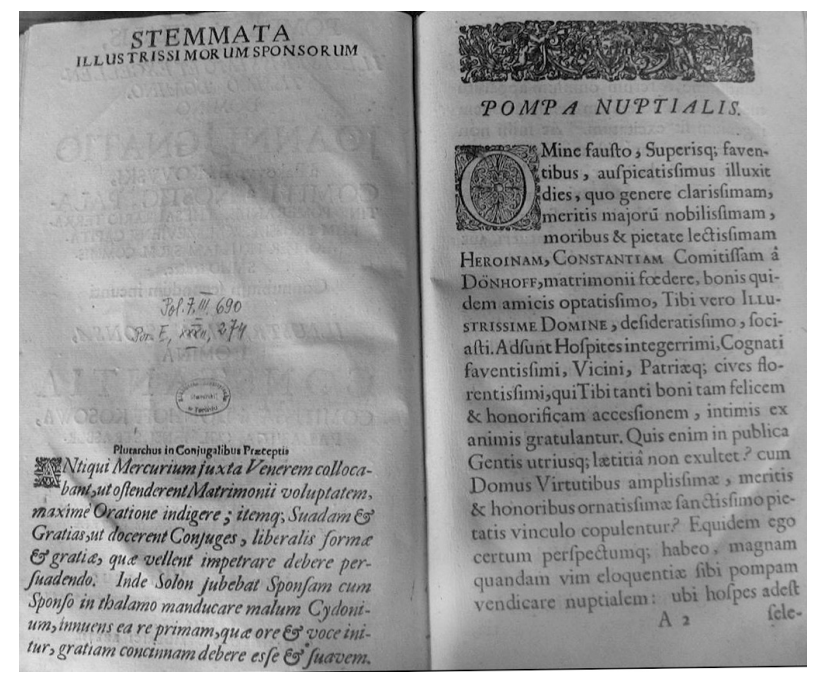

Il. 11 Strona $z$ druku Michaela Webera Pompa nuptialis... bez ryciny. Biblioteka Gdańska PAN, fot. A. Mosingiewicz 